Participatory Educational Research (PER)

Special Issue 2016-II, pp., 130-142; 01 February 2016

Available online at http://www.partedres.com

ISSN: 2148-6123

http://dx.doi.org/10.17275/per.16.spi.2.14

\title{
Opinions of the 8th Grade Students and Teachers Who Participated in TIMSS 2015 on the Test: "The Example of Ağri"
}

\author{
Pınar URAL KELEŞ * and Süleyman AYDIN \\ Ağrı İbrahim Çeçen University, A ğrı, Turkey
}

\begin{abstract}
TIMSS (Trends in International Mathematics and Science Study), is an international serway study that was held to evaluate the $4^{\text {th }}$ and $8^{\text {th }}$ grade students' knowledge and their skills in mathematics and science at four-year intervals by International Educational Assessment Agency IEA Success (International Association for the Evaluation of Educational Achievement). In our country TURKEY, the TIMSS studies are conducted by Ministry of National Education (MoNE) Measurement, Evaluation and Examinations Services. Shortly Timss is defined as the researches of international science and mathematics educations. This survey study is conducted by the International Sudy center in BostonCollege- TIMSS PIRLS. The research to which many country across the globe has participated is a project which affects the education policies of the participatory countries. The aim of this study is to bring out the opinions of the 8th grade students who attended timss 2015 and teachers about the exam. This study has been conducted under case study approach. Case study method offers opportunities only in the case of searching the subject in depth but holistically within the context. Moreover the case study method is suitable to design and analyse for both quantitative and qualitative researches. The study was conducted with 24 students studying in the relevant class of a secondary school of Agri province centre where the exam is held and 6 teachers who give science and mathematic lectures in this school and at the same time participated in TIMSS activity as controllers. The data were collected through a queationnare prepared by the researchers. The data obtained from the study were subjected to descriptive and content analysis. In the study analysis were presented seperately as descriptive analyse and content analyse. As a result of the study, it was concluded that the students havent adequately prepared for the timss exam due to teog exams, the questions were hermeneutical rather than requiring knowledge and awareness level of the the teachers are low.
\end{abstract}

Keywords: TIMSS, Descriptive analysis, Science education, Students and teachers' opinions, Case study.

\section{Introduction}

The basic aim in educational studies is achieving student success. For this reason, countries that aim the success in education have to change and update their educational programs parallel to the developments and the needs in the world, and increase the quality and efficiency of the programs. The most important data source that is taken into consideration by

\footnotetext{
* Education, Science Education Department, yupul@ hotmail.com
} 
countries that seek the answer to the question of how the innovations in educational programs will take place is the International Educational Evaluation Studies. With these evaluation studies, they not only receive information on the educational status in their own countries but also have the opportunity of comparing their educational systems with other countries (Brown and Brown, 2007). One of these evaluation studies which is commonly used is the TIMSS (Trends in International Mathematics and Science Study). This study is applied once in every four years and many countries participate in it to measure and evaluate the levels and inclinations of the $4^{\text {th }}$ and $8^{\text {th }}$ grade students in science and mathematics. In this context, TIMSS acts like a natural laboratory that makes it possible for the participant countries to compare their success levels in education with other countries. With TIMSS evaluation, the level of teaching basic skills in science and mathematics educational programs is measured, and also data are collected with questionnaires applied to students, teachers and schools on many variables that may influence education. Our country participated in TIMSS studies, which were conducted since 1995, in 1999, 2007, 2011 and 2015; but not in 1995 and 2003. In addition, our country participated in this study in 1999 and 2007 at $8^{\text {th }}$ grade level; and in 2011 at $4^{\text {th }}$ and $8^{\text {th }}$ levels. As of the date of this study, the results of the one conducted in 2015 were not released to the press. Around 600.000 students participated at $4^{\text {th }}$ and $8^{\text {th }}$ levels from 63 countries to the TIMSS 2011 whose results have been discussed a lot in our country.

When the results of Mathematics and Science received from TIMSS 2011 are examined the following results are obtained (Oral, \& McGivney, 2013). Although the points our country received from TIMSS 2011 in mathematics increased when compared with the previous years, it was still below the TIMSS scale averages defined for $4^{\text {th }}$ and $8^{\text {th }}$ grades. The average success point of our country in mathematics is 469 at $4^{\text {th }}$ Grade level, and 452 at $8^{\text {th }}$ Grade level and both are below 500, which is the TIMSS scale average point. Turkey was the $35^{\text {th }}$ among 50 countries at $4^{\text {th }}$ Grade level, and $24^{\text {th }}$ among 42 countries at $8^{\text {th }}$ Grade level. Since our country participated in TIMSS at $4^{\text {th }}$ Grade level in 2011 for the first time, it is not possible to compare the results with previous years. At $8^{\text {th }}$ Grade level, on the other hand, the mathematical success level average points of Turkey were almost the same for the years 1999 and 2007 (429 points and 432 points, respectively), an increase of 20 points was observed in 2011 (452 points). Although the average points of Turkey in science improved in TIMSS 2011 when compared with the previous years, the average success points at $4^{\text {th }}$ Grade level was 463 , and 483 at $8^{\text {th }}$ Grade level both being below the TIMSS scale average points. However, it is generally considered that there has been a steady increase in science average points at $8^{\text {th }}$ Grade level since 1999. As for the order among other countries, Turkey is the $36^{\text {th }}$ among 50 countries at $4^{\text {th }}$ Grade level, and $21^{\text {st }}$ among 42 countries at $8^{\text {th }}$ Grade level. Our country achieving success in TIMSS and other similar international tests is only possible by increasing the awareness on such studies and increasing the number of these studies. By doing so, it will be possible to determine the reasons of our students and our country falling below the average levels in the world in international evaluation systems, and guiding the steps to produce solutions for the problems in this context. However, when the relevant literature is examined it is observed that the studies on TIMSS in which the science and mathematics education programs of our country are evaluated are extremely few in number. Based on this fact, the purpose of this study is determining the opinions of the $8^{\text {th }}$ Grade students and teachers who participated in TIMSS 2015 in the city center of Ağrı.

\section{Method}

This study has been conducted with the help of Special Case Approach. This is a method that makes it possible to examine a case in detail. The case to be examined may 
sometimes be a school, a person or a group (Wellington, 2000). This method focuses on the specialty of a case, and makes it possible to use different data collection techniques together (Cohen \& Manion, 1994; Çepni, 2009).

\section{Sampling}

The sampling of this study consists of 24 students from $8^{\text {th }}$ grade, and 6 teachers from a secondary school, which participated in TIMSS 2015, in the city center of Ağrı.

\section{Data Collection Tool}

The data of the study were collected from the students who participated in TIMSS 2015 by written interviews, and from the teachers by verbal interviews. The written interview technique was preferred because of the number of the students participating in the study being high. In the process of determining the questions that would be used in the study, the literature has been made use of (Öztürk, 2010; Öztürk. \& Uçar 2010; Karamustafaoğlu \& Sontay, 2012; Korkmaz, 2010; Atar, 2014; Yatağan, 2014) as well as the results of informal interviews with 3 post graduate level students of the field. The questions prepared were simplified in the light of the opinions of 2 lecturers from the relevant field and reorganized. 6 questions were asked to the students and teachers in the scope of the study. The written interviews with the students lasted for 15-20 minutes, and the interviews with the teachers lasted for approximately 30 minutes. The interviews were recorded with a voice recorder device after the consents of the participants were received.

\section{The Analyses of the Data}

The written interview data of the students have been subjected to descriptive analyses. Content analysis has also been made use of. The content analysis is a systematic technique in which a text is encoded with certain rules and with smaller content categories (Büyüköztürk, 2004: p, 195). Firstly, the data recorded are converted into text, and the data that are related with each other in terms of meaning are collected and interrelated with each other, and tables are formed by using frequency values and percentages $(\%)$. When the tables are formed, different codes are given for different opinions of students. The interviews with the teachers are presented after performing content and descriptive analyses. In the content analysis, the above-mentioned path is followed; while in descriptive analysis, opinions of the teachers are analyzed by considering the significance and importance levels. When necessary, the statements of the teachers are given in quotation marks as are (Büyüköztürk, 2004: p, 195). The teachers who participated in the study are given codes like $\mathrm{T} 1, \mathrm{~T} 2, \ldots$.

\section{Findings}

Under this title, the data received from the students and teachers are given separately.

\section{Findings Received from the Students}

The written interview data received from 24 students who participated in the study are given in percentages and frequencies in tables in the light of the themes. The opinions of the students who participated in the study on TIMSS are given in Table 1 below. 
Tablo 1: The opinions of the students who participated in the study on TIMSS

\begin{tabular}{lllc}
\hline 1. & $\begin{array}{l}\text { QUESTION: What do you know about TIMSS } \\
\text { study? }\end{array}$ & f. & $\%$ \\
\hline $\begin{array}{l}\text { It is a mathematics and science test. } \\
\text { It is a very difficult test. }\end{array}$ & 6 & $25 \%$ \\
$\quad$ I have heard about it for the first time this year. & & \\
\hline - & A test in which the world countries participate. & 14 & $58,33 \%$ \\
\hline - & The success score of our country is low. & 2 & $8,33 \%$ \\
\hline - & It is only conducted in our class. & 2 & $8,33 \%$ \\
\hline
\end{tabular}

When the opinions of the students on TIMSS study are considered it is observed that $25 \%$ of them answered as "It is a mathematics and science test", "It is a very difficult test" "I have heard about it for the first time this year".

The lowest answering percentage to this question belongs to the question "It is only conducted in our class" with 2 students.

The opinions of the students on the question "How did you prepare for the 2015 TIMSS?" are given in Table 2 below.

Tablo 2: Students' Opinions on how they prepared for the TIMSS 2015

\begin{tabular}{lll}
\hline $\begin{array}{l}\text { 2. QUESTION: How did you prepare for TIMSS 2015? Can you tell } \\
\text { us? }\end{array}$ & K.S. & \% \\
- $\quad$ I studied for one week. & 3 & $12,5 \%$ \\
- $\quad$ I studied for the last two or three weeks. & 2 & $8,33 \%$ \\
- $\quad$ I studied from the worksheets and tests our teacher gave us. & 9 & $37,5 \%$ \\
- $\quad$ I studied from course book and my notebook. & 4 & $16,66 \%$ \\
- $\quad$ We studied the past test questions in our classroom. & 3 & $8,33 \%$ \\
- $\quad$ We were made to study in separate classrooms. & 4 & $16,66 \%$ \\
- $\quad$ I did not study for the test. & 4 & $16,66 \%$ \\
\hline
\end{tabular}

As it is observed in Table 2, nine students out of 24 students, i.e. 37,5\% of them, who participated in the study, stated that they studied from the worksheets and tests their teachers gave them, 4 students used the statements "I studied from course book and my notebook", "We were made to study in separate classrooms", "I did not study for the test" to answer the questions. The number of the students who said "I studied for the last two or three weeks" is 2 and the percentage is $8,33 \%$.

The opinions of the students on the questions like "How do you evaluate TIMSS 2015?" and "In your opinion, how were the questions?" are given in Table 3 below. 
Tablo 3 : Students' Opinions on how they evaluate the TIMSS 2015

\begin{tabular}{|c|c|c|}
\hline $\begin{array}{l}\text { 3. QUESTION: How do you evaluate TIMSS 2015? In your opinion, how were the } \\
\text { questions? }\end{array}$ & K.S. & $\%$ \\
\hline - I thought the test would be difficult, but it was not. & 5 & $20,8 \%$ \\
\hline $\begin{array}{l}\text { - I was nervous because I too the TIMSS test for the first time. } \\
\text { - The science questions were easy and the mathematics questions were difficult. }\end{array}$ & 4 & $12,5 \%$ \\
\hline $\begin{array}{l}\text { - I thought it would be easy before the test, but I had many difficulties during } \\
\text { the test. }\end{array}$ & 7 & $29.1 \%$ \\
\hline $\begin{array}{l}\text { - I had no difficulties because I thought about it as a normal test. } \\
\text { - The logic questions were very difficult, but the rest was simple. } \\
\text { - There were some questions from the past years and they were difficult. }\end{array}$ & 5 & $20,8 \%$ \\
\hline - Half of the test was simple and the rest was difficult. & 1 & $4,1 \%$ \\
\hline - It was also a preparation of TEOG test & 6 & $25 \%$ \\
\hline
\end{tabular}

As it is obvious in Table 3, 7 out of 24 students who participated in the study, i.e. $29,1 \%$ of them, used the statement "I thought it would be easy before the test, but I had difficulties during the test" to answer the question. 6 students said "This was also a preparation for TEOG test"; and only one students used the statement "Half of the questions were easy and the rest was difficult". The answers of the students given to the question "Can you compare the questions of TIMSS 2015 and the questions asked at school?" are given in Table 4 below.

Tablo 4: The comparison of the questions of TIMSS 2015 asked at school.

\begin{tabular}{|c|c|c|}
\hline $\begin{array}{l}\text { 4. QUESTION: Can you compare the questions in TIMSS } 2015 \text { and the } \\
\text { questions in the tests at school? }\end{array}$ & K.S. & $\%$ \\
\hline $\begin{array}{l}\text { The questions in TIMSS were asked from the whole secondary school and } \\
\text { therefore we could not remember many topics, so it was more difficult. }\end{array}$ & 3 & $12,5 \%$ \\
\hline $\begin{array}{l}\text { TIMSS test was more difficult, it was complicated. The one at school was } \\
\text { easier. }\end{array}$ & 5 & $20,83 \%$ \\
\hline $\begin{array}{l}\text { Since the questions in TIMSS were multiple choice and were logic questions, } \\
\text { they were easier than the classical questions at school. }\end{array}$ & 8 & $33,33 \%$ \\
\hline $\begin{array}{l}\text { There were more comprehensive questions in TIMS, and some questions were } \\
\text { irrelevant. }\end{array}$ & 3 & $12,5 \%$ \\
\hline $\begin{array}{l}\text { We were more comfortable in TIMSS test because nobody would see the } \\
\text { answers we gave and therefore it was easier. }\end{array}$ & 2 & $8,33 \%$ \\
\hline I think both were easy, to the same level. & 2 & $8,33 \%$ \\
\hline $\begin{array}{l}\text { Mathematics was difficult in TIMSS test, science was easy. Both are equal in } \\
\text { the tests at school. }\end{array}$ & 1 & $4,16 \%$ \\
\hline
\end{tabular}

As it is observed in Table 4, 8 students out of 24 students who participated in the study, i.e. $33,33 \%$ of them, answered the question by using the statement "Since the questions in TIMSS were multiple choice and were logic questions, they were easier than the classical questions at school". $8,33 \%$ of the students, i.e. 2 students, answered the same question by using the statement "We were more comfortable in TIMSS test because nobody would see the answers we gave and therefore it was easier"; and "I think both were easy, to the same level".

The answers to the question "Do you have information on other international tests applied in 
our country other than TIMSS? Please explain" by students are given in Table 5 below.

Tablo 5: Students' opinions on other international tests applied in our country other than TIMSS

\begin{tabular}{|c|c|c|}
\hline $\begin{array}{l}\text { 5. QUESTION: Do you have information on other } \\
\text { international tests applied in our country other than } \\
\text { TIMSS? Please explain }\end{array}$ & K.S. & $\%$ \\
\hline I have no information. & 10 & $41,66 \%$ \\
\hline I have information. PISA & 11 & $45,83 \%$ \\
\hline I was even astonished when I heard the TIMSS Test. & 1 & $4,16 \%$ \\
\hline I know that there is a test called TÖDER. & 1 & $4,16 \%$ \\
\hline I think TEOG is an international test. & 1 & $4,16 \%$ \\
\hline
\end{tabular}

As it is observed in Table 5, 45,83\% of the students who participated in the study answered as "Yes, I have information"; 45,83\% said "Yes, I have information. PISA"; 41,66\% said "I have no information".

The answers of the students given to the question "Do you have information on other international tests applied in our country other than TIMSS 2015?" are given in Table 6 below.

Tablo 6: Students' Opinions on the Contribution of TIMSS and other similar international tests to the Educational System of Turkey

6.QUESTION: According to you, Do the international applications like TIMSS contribute to the education system of Turkey? Please explain.

Yes, it contributes. We had a good preparation especially for TEOG exam.

f $\%$

Yes, it contributes. It ensures us to remember the topics in $6^{\text {th }}, 7^{\text {th }}, 8^{\text {th }}$. class.

$2 \% 8,03$

İt crucially contributes to math and science lessons in Turkey.

$3 \quad \% 12,5$

Yes, it contributes. It ensures to determine our education level and our deficincies.

$2 \% 8,33$

I think, Education al level of Turkey will raise.

$6 \quad \% 25$

Since it is a test at the international level it contributes to Turkey.

$2 \% 8,33$

Yes, it contributes. Because we have learned there the topics that we did not able to learn.

$3 \% 12,5$

It contributes. Because the results of the exam did not be explained the students can do it easily. Their self-confidence rises.

$2 \% 8,33$

I am undecided.

$1 \% 4,16$

I think it contributes.

$2 \% 8,33$

I think that history and geography courses should be added to that of TIMSS test.

$1 \% 4,16$

As it is observed in Table 6, all of the students who participated in the study except fort $12,49 \%$ thought that international tests like TIMSS would contribute to the educational system of Turkey in various ways. $25 \%$ of the students answered as "Yes, they will contribute to the system by making us define our educational level and our missing points". 


\section{Findings Obtained From The Teachers}

The data obtained in the interviews made with 2 mathematics teachers, 2 science teachers and the mathematics and science teachers of the class that took the TIMSS test are given under this title. The reason for including the other mathematics and science teachers of the school in the study is obtaining information on their awareness levels.

The answers of the teachers to the question "Have you ever heard about TIMSS before?" are given in Table 7 below.

Tablo 7: Teachers' opinions on having heard TIMSS before

\begin{tabular}{|c|c|c|c|}
\hline $\begin{array}{l}\text { 1. QUESTION: Have you ever heard about } \\
\text { TIMSS before? }\end{array}$ & T Codes & K.S. & $\%$ \\
\hline I have heard about it this year for the first time. & T4, T5, T6 & 3 & $49,99 \%$ \\
\hline Yes, I know that it is conducted internationally. & $\mathrm{T} 1, \mathrm{~T} 2$ & 2 & $33,33 \%$ \\
\hline $\begin{array}{l}\text { Yes, I have heard about it. I had information on it in } \\
\text { research classes at university. }\end{array}$ & $\mathrm{T} 3$ & 1 & $16,66 \%$ \\
\hline
\end{tabular}

As it is observed in Table 7, 3 teachers out of 6 teachers, i.e. teachers T4, T5 and T6, stated that they had heard the TIMSS test for that year for the first time. The number of the teachers who stated having heard about TIMSS in research classes at university is only 1.

The evaluations of the teachers on the preparation process for TIMSS 2015 are given in Table 8 below.

Tablo 8: Teachers' opinions on evaluating the preparation process for TIMSS 2015

\begin{tabular}{|c|c|c|c|}
\hline $\begin{array}{l}\text { 2. QUESTION: Can you please evaluate the preparation } \\
\text { process for 2015 TIMSS? Did you do sufficient } \\
\text { preparations? Can you share your works? }\end{array}$ & T Codes & K.S. & $\%$ \\
\hline $\begin{array}{l}\text { I think it was not sufficient. We solved the questions from } \\
\text { different years. }\end{array}$ & $\mathrm{T} 1$ & 1 & $16,66 \%$ \\
\hline $\begin{array}{l}\text { I think it was not sufficient. The levels of the questions and } \\
\text { the question types were familiarized with the students and } \\
\text { information on marking the answers were given to the } \\
\text { students. }\end{array}$ & $\mathrm{T} 2$ & 1 & $16,66 \%$ \\
\hline $\begin{array}{l}\text { This test was not applied to the class I taught. I know that my } \\
\text { other colleagues made a lot of studies. However, the time was } \\
\text { not sufficient. }\end{array}$ & $\mathrm{T} 3, \mathrm{~T} 4$ & 2 & $33,33 \%$ \\
\hline $\begin{array}{l}\text { This was not applied to my class, but I tried to solve the } \\
\text { various questions in this test with my students. }\end{array}$ & $\mathrm{T} 5$ & 1 & $16,66 \%$ \\
\hline $\begin{array}{l}\text { This was not applied to my class, but I informed my class } \\
\text { about it. }\end{array}$ & T6 & 1 & $16,66 \%$ \\
\hline
\end{tabular}

It is observed in Table 8 that the mathematics teacher (T1) and science teacher (T2) of the classes in which the TIMSS 2015 application would be applied stated that although they solved problems that were similar to those asked in TIMSS 2015 and gave information on marking, they were not sufficient. Two of the other teachers of the school stated that they did not found the preparations sufficient, and the other two teachers stated that they had informed their classes about the question types that were asked in the test. The opinions of T1 who is 
the mathematics teacher of the class where the test was applied are as follows:

T1; "I think the time was insufficient. We studied for 2-3 weeks, I wish we could prepare for the test more. We have a very tight curriculum, and there is the TEOG Exam. We distributed the mathematics questions to students and solved them in this process".

The opinions and evaluations of the teachers on the preparation process for TIMSS 2015 are given in Table 9 below.

Tablo 9: Teacher opinions and evaluations on TIMSS 2015 application.

\begin{tabular}{|c|c|c|c|}
\hline $\begin{array}{l}\text { 3. QUESTION: How do you evaluate TIMSS } 2015 \\
\text { application? }\end{array}$ & T Codes & K.S. & $\%$ \\
\hline $\begin{array}{l}\text { I have no clear ideas because I do not teach the class where } \\
\text { TIMSS was applied, but I have heard that it is not difficult. }\end{array}$ & $\mathrm{T} 3, \mathrm{~T} 4$ & 2 & $33,33 \%$ \\
\hline I have no information & T6 & 1 & $16,66 \%$ \\
\hline $\begin{array}{l}\text { The students had difficulties because the question types are } \\
\text { different and the time was insufficient }\end{array}$ & $\mathrm{T} 5$ & 1 & $16,66 \%$ \\
\hline $\begin{array}{l}\text { Actually the test was not difficult. Our students do not have } \\
\text { information on these tests. }\end{array}$ & $\mathrm{T} 2$ & 1 & $16,66 \%$ \\
\hline $\begin{array}{l}\text { The students were upset because of the work 'international'. } \\
\text { I think the test consisted of questions that were proper for } \\
\text { the purpose. }\end{array}$ & $\mathrm{T} 1$ & 1 & $16,66 \%$ \\
\hline
\end{tabular}

As it is observed in Table 9, all of the students who participated in the interviews except one stated that the questions in the test were in fact not difficult, and added that they had difficulties due to different reasons. The types of the questions, the time being insufficient, not having sufficient information on these types of tests and being nervous are among these reasons. The opinions of the teachers whose codes are $\mathrm{T} 1$ and $\mathrm{T} 2$, who are the mathematics teachers of the class where the test was applied, on the question are as follows.

T1; "The students were upset because of the word 'international test'. The level of stress and anxiety was extremely high. They already had stress because of the TEOG exams. This situation may have been reflected to the test. Otherwise, I think the test consisted of questions that were proper for the purpose".

T2; "The students were not aware of the question types in this type of tests before the actual test date. Although we solved different question types, a few weeks was not sufficient, they cannot do this. They said 'Were these questions that easy?' for some questions, but they could not solve them in the test".

The opinions and evaluations of the teachers on the preparation process for TIMSS 2015 are given in Table 10 below.

Tablo 10: The opinions of the teachers on the success levels of our country in TIMSS Applications

\begin{tabular}{llll}
$\begin{array}{l}\text { 4. QUESTION: Do you have any information } \\
\text { on the previous success levels of our country in } \\
\text { TIMSS applications? }\end{array}$ & $\begin{array}{l}\text { T Codes } \\
\text { No. }\end{array}$ & K.S. & $\%$ \\
No & $\begin{array}{lll}\text { T6, } \\
\text { T5, T4 }\end{array}$ & $33,33 \%$ \\
\hline
\end{tabular}




\begin{tabular}{llll}
\hline $\begin{array}{l}\text { Yes, I have the information. Unfortunately our } \\
\text { success level is low. }\end{array}$ & T1 & 1 & $16,66 \%$ \\
$\begin{array}{l}\text { Yes. Our success level is low. Our mathematics } \\
\text { success is lower than our success level in science. }\end{array}$ & T2 & 1 & $16,66 \%$ \\
$\begin{array}{l}\text { I do not clearly know, but I learnt from a } \\
\text { questionnaire that the success level of our country } \\
\text { is low in previous years. }\end{array}$ & T3 & 1 & $16,66 \%$ \\
\hline
\end{tabular}

As it is observed in Table 10, 3 teachers out of the 6 teachers who participated in the interview, have information on the success level of our country in TIMSS Applications, and 3 teachers stated that they did not have any information on this topic. One of the teachers stated that $\mathrm{s} /$ he did not have any clear ideas about the topic. The opinions of the teacher $\mathrm{T} 2$, who is the Science and Technology Teacher of the class where TIMSS was applied, on this topic are as follows.

T2; "Yes, unfortunately our success is low. Our mathematics success level is lower than science. I know that our science success is better, especially in $8^{\text {th }}$ grade. High school entrance tests may have an influence in this".

The opinions of the teachers on the question "Why cannot our country have high success in TIMSS tests?" are given in Table 11 below.

Tablo 11: Teachers' opinions on why our country cannot show high-level success in TIMSS Applications

\begin{tabular}{|c|c|c|c|}
\hline $\begin{array}{l}\text { 5. QUESTION: Why cannot our country have high } \\
\text { success in TIMSS tests? }\end{array}$ & TC & K.S. & $\%$ \\
\hline $\begin{array}{l}\text { The classes are crowded, the parents of the students are } \\
\text { not interested, insufficient number of teachers, lack of } \\
\text { student involvement, students do not have the } \\
\text { enthusiasm for studying further, and students pass their } \\
\text { grades without studying. }\end{array}$ & $\mathrm{T} 3, \mathrm{~T} 2, \mathrm{~T} 1, \mathrm{~T} 6, \mathrm{~T} 4$ & 4 & $66.4 \%$ \\
\hline The questions are very different in TIMSS application & $\mathrm{T} 1, \mathrm{~T} 2, \mathrm{~T} 3, \mathrm{~T} 5$ & 3 & $49.8 \%$ \\
\hline Prejudice against science and mathematics classes & T5, T3 & 2 & $33,33 \%$ \\
\hline $\begin{array}{l}\text { Our country cannot be regarded as unsuccessful, we are } \\
\text { increasing our success, though partly. }\end{array}$ & $\mathrm{T} 2$ & 1 & $16,66 \%$ \\
\hline $\begin{array}{l}\text { Lacking investments on education or the investments are } \\
\text { spent on unnecessary expenses, and the use of black } \\
\text { boards in classes. }\end{array}$ & T6 & 1 & $16,66 \%$ \\
\hline
\end{tabular}

As it is observed in Table 11, T3, T2, T1 and T6 said "The classes are crowded, the parents of the students are not interested, insufficient number of teachers, lack of student involvement, students do not have the enthusiasm for studying further, and students pass their grades without studying" about why our country cannot show success in TIMSS Applications. T1, $\mathrm{T} 2$, T3, and T5 showed the reason of this as the questions being very different in TIMSS Applications, and T5 and T3 showed the prejudice against science and mathematics classes as the reason. In addition to this, T2 said that our country had increased its success in science in the last application and could not be regarded as unsuccessful. The opinions of T5 and T6, who are the mathematics teachers of the school, on this topic are as follows. 
T5; "For once, the questions in our tests and the ones in TIMSS Applications are very different from each other. For this reason, of course our success will be low in such tests, and in addition, the classes are crowded, the parents of the students lack sufficient interest, the number of the teachers are few especially in the eastern part of our country, the students lack the enthusiasm for further studying, passing the grades is easy, students can pass the classes without studying. Moreover, the students have too much prejudice against science and mathematics classes."

T6; "The classes are crowded, the parents lack the interest in their students, the number of teachers is insufficient and the students do not want to study further, and yet, they pass to upper grade. In addition, I think necessary investments are not made on education, or the investments are spent on unnecessary things, for example, the blackboards are still used in classes."

The opinions of the teachers on the question "Do you think TIMSS Application has contributions to our educational system?" are given in Table 12 below.

Tablo 12: Teachers' Opinions on the Contribution of TIMSS Application to our educational system

\begin{tabular}{|c|c|c|c|}
\hline $\begin{array}{l}\text { 6. QUESTION: Do you think TIMSS Application } \\
\text { has contributions to our educational system? }\end{array}$ & T Codes & K.S. & $\%$ \\
\hline I think it has made contributions. & $\mathrm{T} 1, \mathrm{~T} 2, \mathrm{~T} 3, \mathrm{~T} 4, \mathrm{~T} 5$ & 5 & $83 \%$ \\
\hline I do not think so. & T6 & 1 & $16,66 \%$ \\
\hline
\end{tabular}

As it is observed in Table 12, all of the teachers who participated in the study defended that the TIMSS Application had contributions to our educational system. The opinions of T2 and T3 are as follows.

T3; "Success in our side stays only in theory, because our questions are very different from the ones in the TIMSS Application. I think it contributed to us by showing that our evaluation system was not right. I think the success of our country will increase."

T2; "I think it contributed to us because it made us see our success and place at international level in science and mathematics."

\section{Discussion}

This study has been conducted to reveal the opinions of the $8^{\text {th }}$ Grade students and the teachers who run the TIMSS 2015 Application about the application in the city center of Ağr1. When the data obtained in the study are examined it is observed in Table 1 that the students had information on TIMSS Applications at basic level. It is also observed in Table 2 that $16,6 \%$ of the students did not make any preparations for the application, and all of the others prepared in different ways for this application. Karabacak (2010) stated that students could not allocate time for social, cultural and other important activities because of the high school placement exams; and Öztürk (2010) stated that the reason of our country not being successful at the desired level was partly due to the fact that students did not have the enthusiasm for educational activities. Aktaş (2011) reported that 65\% of TIMSS 2007 Turkey science variance could be explained with variables that were related to the students. Karamustafaoğlu \& Sontay (2012) conducted a study on TIMSS 2011 and reported that 15\% of the $8^{\text {th }}$ Grade students stated that they did not have any ideas on the application, and $65 \%$ 
of them stated that they did not prepare well for the test. Based on this, it is possible to claim that students are more aware of the TIMSS Applications when compared with the past and the majority of them make preparations for this application.

As it is stated in Table 3,29\% of the students who participated in the study stated that they found the questions in TIMSS 2015 difficult, and had difficulties in solving them, 20,1\% of them stated that the questions were easier than they had expected, and 20,1\% of them stated that they considered the application as a normal test and therefore did not have any difficulty. This situation may be commented as $40 \%$ of the students did not have difficulty in the application.

After 2011 TIMSS, 30\% of the students said "The questions were easy" (Karamustafaoğlu \& Sontay 2012). Another result obtained in this study is, as it is observed in Table 5, the majority of the students (around 46\%) found the questions asked in TIMSS Application to be more difficult, complex and comprehensive than the questions asked at school, and stated that they required logical thinking. There have been other studies reporting that students stated that the questions asked in TIMSS Applications were logic questions and they had difficulty in answering these questions (Karamustafaoğlu \& Sontay 2012). It is known that the questions asked in TIMSS Applications require upper-level thinking skills when compared with the questions asked in our schools (Aslan 2005; Yatağan, 2014). As a matter of fact, raising science-literate individuals requires developing the questioning sides of the students (Chamberlain and Crane, 2009).

When the data obtained from the teachers in the study are examined it is observed that the majority of the teachers had no information on TIMSS Applications and some of them stated that the preparation process was not sufficient. This result shows parallelism to the results obtained in the studies conducted by Öztürk (2010) and Karamustafaoğlu \& Sontay (2012) in which the 20072011 TIMSS Applications were evaluated. In addition, all of the teachers except one stated that the questions asked in the application were not very difficult and added that the students were alien to such questions. In a study conducted by Aslan (2005) it was reported that the questions asked in schools had the purpose of selecting and eliminating students and were multiple choice questions in Turkey; however, the questions used in testing systems at schools in Singapore, which has proven its success in TIMSS Applications, are both multiple-choice and open-ended questions and are directed to guide students; and this also supports the results.

Yatağan (2014) conducted a study and reported that although the rate of asking questions that are directed to "designing scientific research and developing hypotheses" and require upperlevel thinking skills increased in 2011 when compared with the rate in 2007, teachers continue to ask the questions that are heavily directed to "know" the subject.

The reasons why our country could not achieve success in TIMSS Applications was associated with different factors by the teachers who participated in our study. In the first order, there is the issue of the classes being crowded, the lack of interest by the parents in their children, insufficient number of teachers, lack of effort by the students, the students' not having the enthusiasm for studying further, and students passing their grades although they do not study. This is followed by the questions asked in TIMSS Applications being different, and the students having prejudice against science and mathematics classes. When the relevant literature is examined it is observed that teachers consider the crowded classes and the lack of interest by the parents as important problems for conducting the program (Geçer and Özel, 
2012; Öztürk, 2010; Karamustafaoğlu \& Sontay, 2012; Yatağan, 2014). It has been determined in the study that the prejudices of the students against science and mathematics classes might be influential in the TIMSS Application results obtained in the study. Öztürk (2010) conducted a study and also reported similar results. Although Baykul (1990) conducted a study and reported that the attitudes of students for science and mathematics classes changed in the negative direction continuously from primary school $5^{\text {th }}$ Grades until the last grade in high schools; Yatağan, (2014) reported that the rate of the students who stated that they loved learning science was $88,4 \%$ in TIMSS 2011; it reached $91,7 \%$ in TIMSS 2011. It is hoped that this important factor will influence the success of our country in national and international examinations.

\section{Recommendations}

This study has been conducted to reveal the opinions of the $8^{\text {th }}$ Grade students and the teachers in the city center of Ağr1 and who participated in TIMSS 2015 about the application. Based on the results obtained in the study it has been determined that both the students and the teachers were not ready for the TIMSS Applications at a sufficient level and the awareness level was low. It is considered that the level of awareness of the teachers and students may be increased with an efficient guidance. In addition, applications like this must be prepared in an organized manner with the help of the MoNE (the Ministry of National Education) and other relevant institutions. In addition to these, it is also among the recommendations of the study that especially the measurement and evaluation methods in science and mathematics classes must be run in accordance with international testing applications.

\section{References}

Aktaş, I. (2011). Examining the relationship between students? science achievement and teachers? characteristics in TIMSS 2007, (Unpublished master's thesis). Hacettepe University, Graduate School of Social Sciences, Ankara.

Aslan, F. (2005). Comparing science education program of Turkey with science education program of Singapore according to TIMSS-R, (Unpublished master's thesis). Hacettepe University, Graduate School of Social Sciences, Ankara.

Atar, H.Y. (2014). Ö̈̆retmen Niteliklerinin TIMSS 2011 Fen Başarısına Çok Düzeyli Etkileri, Education \& Science / Egitim ve Bilim . 2014, Vol. 39 Issue 172, p121-137. $17 \mathrm{p}$.

Baykul, Y. (1990). İlkokul Beşinci Sınıftan Lise ve Dengi Okulların son Sınıflarına kadar Matematik ve Fen Derslerine karşı Tutumda Görülen Değişmeler ve Öğrenci Seçme Sınavındaki Başarı ile İlişkili olduğu Düşünülen Bazı Faktörler. Ankara: ÖSYM Yayınları. http://www.osym.gov.tr/belge/1-127/basilmis-arastirma-veincelemeler.html

Brown, A. S. \& Brown, L. L. (2007). What are science and math test scores really telling us?, The Bent of Tau Beta P., 13-17. http://www.tbp.org/pubs/Features/W07Brown. (10.09.2014)

Büyüköztürk, Ş., (2004) Sosyal Bilimler Iç̧in Veri Analizi El Kitabı [Handbook Of Data Analysis For Social Sciences], 4. Bask1, Ankara: Pegema Yayınc1lık,

Chamberlain, K. \& Crane, C.C. (2009) Reading, Writing and Inquiry in the Science Classroom, Grades 6-12. California: Corwin Press.

Cohen, L. ve Manion, L. (1994). Research Methods in Education. (Fourth Edition), Newyork: Rutledge. 
Çepni, S. (2009). Araştırma ve Proje Çalışmalarına Giriş Introduction to Research And Projects Studies]. (Revised Edition). Trabzon: Celepler Matbaacılik

Oral, I., \& McGivney, E. (2013). Türkiye'de Matematik ve Fen Bilimleri Alanlarında Öğrenci Performansı ve Başarının Belirleyicileri Tımss 2011 Analizi. http://erg.sabanciuniv.edu/sites/erg.sabanciuniv.edu/files/ERG\%20TIMSS\%202011\%20Analiz\%20Raporu-03.09.2013.pdf

Geçer, A. \& Özel, N. (2012) Elementary science and techology teachers ${ }^{\text {ee }}$ views about problems encountered in the instruction process. Educational Science: Theory \& Practice, 12 (3), 2256-2261.

Karabacak, K. (2010). Educational dilemmas caused by SBS, (Unpublished master's thesis). Abant İzzet Baysal University, Institue of Social Sciences, Bolu.

Karamustafaoğlu, O., \& Sontay, G. (2012). Bir TIMSS sınavının ardından: TIMSS 2011'e katılan öğrenci ve uygulayıc1 öğretmenlerin görüşleri http://kongre.nigde.edu.tr/xufbmek/dosyalar/tam_metin/ (09.08.2015)

Korkmaz, F. (2010). Contribution of Some Factors to Eighth Grade Students" Science Achievement in Turkey: TIMSS 2007. (Unpublished master's thesis). Middle East Technical University Graduate School of Natural and Applied Science, Ankara.

Öztürk, D. ve Uçar, S. (2010) TIMSS verileri kullanılarak Tayvan ve Türkiyeeedeki 8. sınıf öğrencilerinin fen başarısına etki eden faktörlerin belirlenmesi ve karşılaştırılması. Çukurova Üniversitesi Sosyal Bilimler Enstitüsü Dergisi, 19(3), 241-256. http://dergipark.ulakbim.gov.tr/cusosbil/article/view/5000001459/5000002150

Öztürk, L. (2010) TIMSS 2007 and success of our educational system: Views of educators and school administration, (Unpublished master's thesis). Marmara University, Institue of Social Sciences, İstanbul.

Wellington, J., (2000). Educational Research, Continuum, London and New York 